\title{
Analisa Tegangan Jatuh pada Sistem Distribusi Listrik di Kapal Penumpang dengan Menggunakan Metode Simulasi
}

\author{
Muhammad F. Wahyudianto, Sardono Sarwito, dan Adi Kurniawan \\ Jurusan Teknik Sistem Perkapalan, Fakultas Teknologi Kelautan, Institut Teknologi Sepuluh \\ Nopember (ITS) \\ Jl. Arief Rahman Hakim, Surabaya 60111 Indonesia \\ e-mail:sarsan@its.ac.id
}

\begin{abstract}
Abstrak-Kebutuhan akan listrik di kapal saat ini sangat tinggi, karena hampir semua aktivitas di kapal seperti berlayar, bermanuver, bongkar muat dan lego jangkar membutuhkan konsumsi listrik yang besar. Pada berbagai macam kondisi tersebut perlu diketahui seberapa besar nilai losses tegangan atau tegangan jatuh dan cara untuk melakukan perbaikan tegangan jatuh. Pada penulisan tugas akhir akan dikaji secara teknis cara melakukan perhitungan tegangan jatuh secara manual dan membandingkannya dengan simulasi software. Pada simulasi software digunakan load flow analysis dan motor acceleration analysis sebagai metode untuk melakukan perhitungan tegangan jatuh secara simulasi. Hasil yang diperoleh terdapat tegangan jatuh terbesar pada kondisi maneuver, saat starting bow thruster terdapat tegangan jatuh selama 60 detik yang tidak sesuai dengan standar IEC 5\% dan tidak direkomendasikan oleh IEEE. Setelah dilakukan perbaikan pada bow thruster dengan cara menaikkan tap transformator sebesar $2,5 \%$ dengan tegangan sekunder $400 \mathrm{~V}$ pada hasil running load flow analysis dan memberi kapasitor sebesar 2000 kVAr, tegangan jatuh pada hasil running motor acceleration analysis tegangan jatuh dapat diturunkan menjadi 13 detik yang sesuai dengan standar IEC dan rekomendasi IEEE.
\end{abstract}

Kata Kunci-load flow analysis, motor acceleration analysis, sistem kelistrikan kapal, tegangan jatuh

\section{PENDAHULUAN}

$\mathrm{I}^{\mathrm{n}}$ ndonesia adalah salah satu negara maritim terbesar di kawasan Asia Tenggara. Hampir semua kegiatan ekspor dan impor menggunakan media transportasi laut mengingat barang yang akan dibawa merupakan kebutuhan pokok seperti minyak, beras, gandum dan kebutuhan industri yang menunjang lainnya dalam jumlah besar. Saat ini kebutuhan listrik di kapal sangat tinggi, karena hampir semua aktivitas di kapal membutuhkan listrik. Kapal sendiri memiliki beberapa kondisi yaitu berlayar (sailing), bermanuver (maneuvering), bongkar muat (cargo handling) dan lego jangkar (anchoring) semua membutuhkan konsumsi listrik yang besar, terutama pada saat kapal dalam kondisi bermanuver (maneuvering) dan bongkar muat (cargo handling). Berbagai macam kondisi kapal tersebut membuat kualitas energi listrik sangat penting, bahkan telah menjadi salah satu faktor utama. Kualitas tegangan yang buruk dapat menyebabkan kerusakan pada alat-alat listrik yang ada di kapal. Tegangan jatuh atau drop voltage ialah suatu kondisi dimana jumlah tegangan yang disalurkan tidak sama dengan tegangan yang diterima persis penerimanya (beban listrik). Kondisi tersebut mengakibatkan kualitas tegangan menjadi buruk dan mengakibatkan arus listrik menjadi tinggi.

Tegangan jatuh adalah selisih antara tegangan ujung pengiriman dan tegangan ujung penerima. Akibat jatuh tegangan yang melebihi toleransi mengakibatkan banyak peralatan elektronik yang tidak bisa bekerja secara maksimal bahkan beberapa mengalami kerusakan. Peningkatan beban yang bersifat induktif dapat mengakibatkan pada penurunan faktor daya, peningkatan rugi-rugi jaringan, penurunan tegangan khususnya pada ujung saluran dan regulasi tegangan yang memburuk. [1] Metode perhitungan tegangan jatuh dengan cara load flow analysis menggunakan software sangatlah membantu dengan hasil yang lebih baik atau lebih presisi daripada melakukannya dengan sistem manual. Dengan mengetahui data aktual single line diagram kemudian dapat disimulasikan pada software untuk segera dianalisa apakah terjadi under voltage pada tiap bus penyulang. Load flow analysis yang disimulasikan dengan software menggunakan metode Newton-Rapshon. Apabila terjadi suatu kegagalan sistem atau sistem tersebut bermasalah software akan memberikan tanda warna merah. Load flow studies bisa digunakan juga untuk mengoptimalkan size dan lokasi dari kapasitor apabila terjadi under voltage. [2]

Load flow studies digunakan untuk mengetahui aliran daya listrik yang ditransfer dari generator kepada beban-beban listrik yang melewati grid system dengan stabil, keandalan penuh, dan ekonomis. [3] Perencanaan single line diagram pada software yang mana juga dapat melihat karakteristik motor induksi. Software memiliki dua metode perhitungan starting motor induksi yaitu dynamic motor acceleration dan static motor acceleration. [4] Power station adalah sofware untuk power system yang bekerja berdasarkan perencanaan (plant/project). Setiap plant harus menyediakan modeling peralatan dan alat - alat pendukung yang berhubungan dengan analisis yang akan dilakukan. Power station dapat melakukan penggambaran single line diagram secara grafis dan mengadakan beberapa analisis / studi yakni load flow (aliran daya), short circuit (hubung singkat), motor starting, harmonics power systems, transient stability dan protective device coorination. [5] Alternatif yang dapat dilakukan untuk memperbaiki profil tegangan jatuh adalah dengan memasang kapasitor seperti pada gambar 1. [1] 


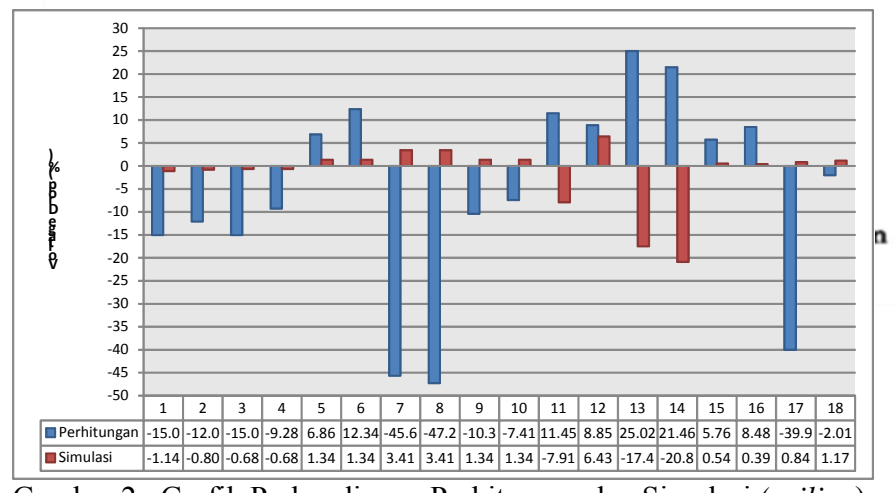

Gambar 2. Grafik Perbandingan Perhitungan dan Simulasi (sailing)

\section{METODE PENELITIAN}

\section{A. Pengambilan Data Lapangan}

Sebelum melakukan metode perhitungan dan simulasi

Tabel 1. Spesifikasi Peralatan

\begin{tabular}{cccc}
\hline \hline Nama Peralatan & $\begin{array}{c}\mathrm{P} \\
(\mathrm{kW})\end{array}$ & $\begin{array}{c}\mathrm{V} \\
(\mathrm{V})\end{array}$ & $\begin{array}{c}\mathrm{I} \\
(\mathrm{A})\end{array}$ \\
\hline Fan Engine Room (PS Fore) & 24,2 & 400 & 50 \\
Fan Engine Room (PS After) & 24,2 & 400 & 50 \\
Fan Engine Room (SB Fore) & 24,2 & 400 & 50 \\
Fan Engine Room (SB After) & 24,2 & 400 & 50 \\
Fan A/E (PS) & 16,5 & 400 & 33 \\
Fan A/E (SB) & 16,5 & 400 & 33 \\
Fan Separator (Sup) & 7,5 & 400 & 14,8 \\
Fan Separator (Exh) & 7,5 & 400 & 14,8 \\
Fan C/R (Sup) & 11 & 400 & 22,5 \\
Fan C/R (Exh) & 11 & 400 & 22,5 \\
Fan S/G & 2,5 & 400 & 2,1 \\
MDO Trans & 5,5 & 400 & 10,9 \\
MDO Booster & 1,1 & 400 & 2,65 \\
LO Pump & 1,5 & 400 & 3,45 \\
CO FW Pump & 48 & 400 & 92 \\
CO SW Pump & 38 & 400 & 75 \\
Hydropore & 15,5 & 400 & 28,5 \\
Steering Gear & 48 & 400 & 85 \\
Ballast Pump & 15,5 & 400 & 28,5 \\
Windlass & 42 & 400 & 73 \\
Bow Thruster & 736 & 400 & 1345 \\
\hline \hline
\end{tabular}

tegangan jatuh yang ada di kapal, data penelitian harus diperoleh terlebih dahulu melalui pengamatan langsung kondisi sistem distribusi listrik dan peralatan listrik di kapal sebagai objek yang akan diteliti. Data hasil pengamatan lapangan dan spesifikasi peralatan terdapat pada Tabel 1.

\section{B. Metode Perhitungan}

Data hasil pengamatan langsung di lapangan kemudian diolah melalui metode perhitungan dengan cara melihat tegangan pada sisi kirim atau sumber listrik di kapal dan membandingkannya dengan tegangan dari sisi terima. Rugi tegangan dapat dinyatakan dengan:

$\Delta V=V s-V r$

Dimana,

$\Delta \mathrm{V}:$ Tegangan jatuh (V)

$\mathrm{V}_{\mathrm{s}} \quad$ : Tegangan kirim $(\mathrm{V})$

$\mathrm{V}_{\mathrm{r}} \quad$ : Tegangan terima $(\mathrm{V})$
Maka besar nilai presentase (\%) tegangan jatuh adalah :

$\Delta V(\%)=\frac{\Delta V}{V} \times 100 \%$

Dimana,

$\Delta \mathrm{V}(\%)$ : Tegangan jatuh dalam (\%)

$\Delta \mathrm{V} \quad$ : Tegangan jatuh (V)

$\mathrm{V} \quad$ : Tegangan kerja (V)

\section{Metode Simulasi Load Flow Analysis}

Voltage drop itu terjadi pada sistem distribusi, dengan cara menganalisa daya 3 phase beserta perhitungannya menggunakan media digital komputer. Memberikan rekomendasi kepada praktisi engineer untuk dapat memilih beberapa metode analisis untuk menganalisa terjadinya voltage drop dengan baik. [6] Proses pengolahan data dengan simulasi dilakukan dengan cara melakukan penggambaran one line diagram pada software. Kemudian hasil dapat diambil dan dilakukan analisa data sebagai penunjang untuk melakukan perbandingan dengan hasil yang diperoleh dari perhitungan.

\section{Metode Simulasi Starting Analysis}

Metode simulasi dengan menggunakan motor acceleration analysis digunakan untuk menganalisa performa motor induksi pada saat starting maupun saat running. Bertujuan untuk mengetahui starting motor induksi yang digunakan di kapal, merujuk pada standar IEC 5\% [7] dan sesuai rekomendasi IEEE. [8] Tegangan jatuh menurut rekomendasi IEEE selama operasional 60 detik pertama tidak boleh melebihi 5\% sesuai standar IEC. [9]

\section{HASIL DAN ANALISA}

Pada sub-seksi ini, dilakukan perhitungan dan simulasi dari data yang telah didapat sesuai dengan kondisi kapal, kemudian melakukan analisa performa motor-motor listrik yang digunakan dalam objek penelitian sesuai data yang telah didapatkan.

\section{A. Kondisi Sailing}

Pada saat kapal dalam kondisi sailing beban listrik disuplai oleh dua unit generator dengan daya masing - masing sebesar $800 \mathrm{~kW}$ dan satu unit transformator dengan daya $2400 \mathrm{kVA}$. Pada saat kapal dalam kondisi sailing beban tertinggi ada pada steering gear, sea water cooling pump dan fresh water cooling pump dengan masing - masing daya $48 \mathrm{~kW}, 48 \mathrm{~kW}$ dan 38 $\mathrm{kW}$. Perbandingan hasil prosentase tegangan jatuh untuk mengetahui apakah nilai tegangan jatuh yang dihitung secara manual dengan simulasi software mengalami perbedaan yang signifikan, pada Gambar 2 dan Tabel 2 kondisi sailing ditunjukkan hasil perhitungan lebih banyak memiliki nilai tegangan jatuh kurang dari standar IEC 5\% [7] dibandingkan dengan hasil simulasi, dikarenakan berbagai faktor eksternal yang mempengaruhi kondisi lapangan sedangkan pada hasil simulasi dipengaruhi oleh faktor kurangnya input data yang sesuai kondisi riil di lapangan, sehingga membuat hasil simulasi software kurang maksimal. 


\section{B. Kondisi Loading Unloading}

Pada saat kapal dalam kondisi loading unloading beban listrik disuplai oleh dua unit generator dengan daya masing masing $800 \mathrm{~kW}$ dan satu unit transformator dengan daya 2400 kVA. Pada saat kapal dalam kondisi loading unloading beban tertinggi ada pada ballast pump, sea water cooling pump dan fresh water cooling pump dengan masing - masing daya 15,5 $\mathrm{kW}, 48 \mathrm{~kW}$ dan $38 \mathrm{~kW}$. Kondisi loading unloading kapal penumpang berbeda dari kapal niaga lainnya yang beban puncak konsumsi listrik terbesar di kapal terletak pada kondisi loading unloading yang biasanya digunakan untuk peralatan permesinan geladak seperti crane dan permesinan bongkar muat pada kapal tanker, sedangkan pada kapal penumpang Tabel 2. Nilai Error Perhitungan dan Simulasi (sailing)

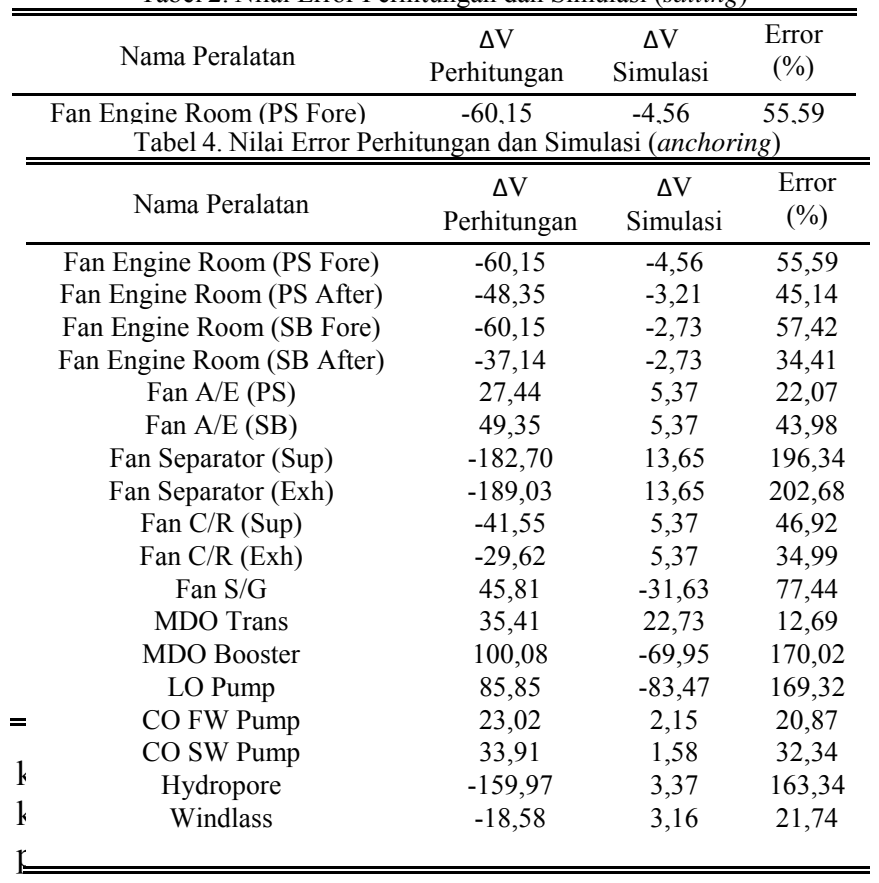

unloading ditunjukkan hasil perhitungan lebih banyak memiliki nilai tegangan jatuh kurang dari standar IEC 5\% [7] dibandingkan dengan hasil simulasi, dikarenakan berbagai faktor eksternal yang mempengaruhi kondisi lapangan sedangkan pada hasil simulasi dipengaruhi oleh faktor kurangnya input data sesuai seperti kondisi kondisi aslinya di kapal, sehingga membuat hasil simulasi software kurang maksimal dan tidak mendekati nilai perhitungan.

\section{Kondisi Anchoring}

Pada saat kapal dalam kondisi anchoring disuplai oleh dua unit generator dengan daya masing - masing $800 \mathrm{~kW}$ dan satu unit transformator dengan daya $2400 \mathrm{kVA}$. Pada saat kapal dalam kondisi anchoring beban tertinggi ada pada windlass, sea water cooling pump dan fresh water cooling pump dengan masing - masing daya $42 \mathrm{~kW}, 48 \mathrm{~kW}$ dan $38 \mathrm{~kW}$. Perbandingan hasil perhitungan tegangan jatuh didapatkan dari data yang diperoleh dari pengamatan langsung di kapal penumpang yang digunakan sebagai objek penelitian dan hasil simulasi load flow analysis sesuai pada gambar 4 . Perbandingan hasil perolehan prosentase tegangan jatuh ini bertujuan untuk mengetahui apakah nilai tegangan jatuh kondisi anchoring kapal penumpang yang dihitung secara

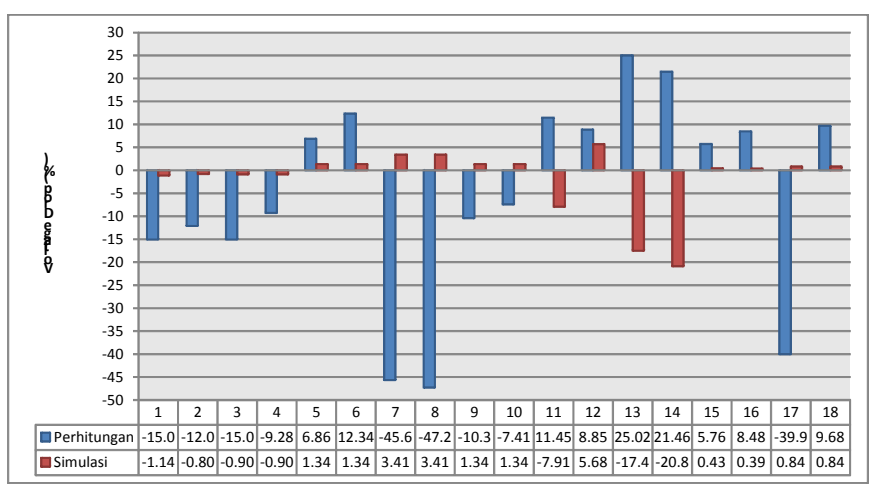

Gambar 3. Grafik Perbandingan Perhitungan dan Simulasi (loading unloading)

manual dan dengan menggunakan simulasi software Tabel 3. Nilai Error Perhitungan dan Simulasi (loading unloading)

\begin{tabular}{|c|c|c|c|}
\hline Nama Peralatan & $\begin{array}{c}\Delta \mathrm{V} \\
\text { Perhitungan }\end{array}$ & $\begin{array}{c}\Delta \mathrm{V} \\
\text { Simulasi }\end{array}$ & $\begin{array}{c}\text { Error } \\
(\%)\end{array}$ \\
\hline Fan Engine Room (PS Fore) & $-60,15$ & $-4,56$ & 55,59 \\
\hline Fan Engine Room (PS After) & $-48,35$ & $-3,21$ & 45,14 \\
\hline Fan Engine Room (SB Fore) & $-60,15$ & $-3,60$ & 56,55 \\
\hline Fan Engine Room (SB After) & $-37,14$ & $-3,60$ & 33,54 \\
\hline Fan A/E (PS) & 27,44 & 5,37 & 22,07 \\
\hline \multicolumn{4}{|c|}{ Tabel 5. Nilai Error Perhitungan dan Simulasi (manuevering) } \\
\hline Nama Peralatan & $\begin{array}{c}\Delta \mathrm{V} \\
\text { Perhitungan }\end{array}$ & $\begin{array}{c}\Delta \mathrm{V} \\
\text { Simulasi }\end{array}$ & $\begin{array}{c}\text { Error } \\
(\%)\end{array}$ \\
\hline Fan Engine Room (PS Fore) & $-60,15$ & $-4,56$ & 55,59 \\
\hline Fan Engine Room (PS After) & $-48,35$ & $-3,21$ & 45,14 \\
\hline Fan Engine Room (SB Fore) & $-60,15$ & $-2,73$ & 57,42 \\
\hline Fan Engine Room (SB After) & $-37,14$ & $-2,73$ & 34,41 \\
\hline Fan A/E (PS) & 27,44 & 5,37 & 22,07 \\
\hline Fan A/E (SB) & 49,35 & 5,37 & 43,98 \\
\hline Fan Separator (Sup) & $-182,70$ & 13,65 & 196,34 \\
\hline Fan Separator (Exh) & $-189,03$ & 13,65 & 202,68 \\
\hline Fan C/R (Sup) & $-41,55$ & 5,37 & 46,92 \\
\hline Fan C/R (Exh) & $-29,62$ & 5,37 & 34,99 \\
\hline Fan $\mathrm{S} / \mathrm{G}$ & 45,81 & $-31,63$ & 77,44 \\
\hline MDO Trans & 35,41 & 22,73 & 12,69 \\
\hline MDO Booster & 100,08 & $-69,95$ & 170,02 \\
\hline LO Pump & 85,85 & $-83,47$ & 169,32 \\
\hline CO FW Pump & 23,02 & 2,15 & 20,87 \\
\hline CO SW Pump & 33,91 & 1,58 & 32,34 \\
\hline Hydropore & $-159,97$ & 3,37 & 163,34 \\
\hline Windlass & $-18,58$ & 3,16 & 21,74 \\
\hline Bow Thruster & 20,15 & 22,11 & 1,96 \\
\hline
\end{tabular}

lapangan sedangkan pada nası simulası dipengarunı olen faktor kurangnya input data sesuai seperti kondisi di kapal, sehingga membuat hasil simulasi software kurang maksimal dan tidak mendekati nilai perhitungan.

\section{Kondisi Manuevering}


Pada saat kapal dalam kondisi anchoring disuplai oleh dua unit generator dengan daya masing - masing $800 \mathrm{~kW}$, dua unit transformator dengan daya $2400 \mathrm{kVA}$ dan $900 \mathrm{kVA}$ transformator khusus untuk beban bow thruster. Pada saat

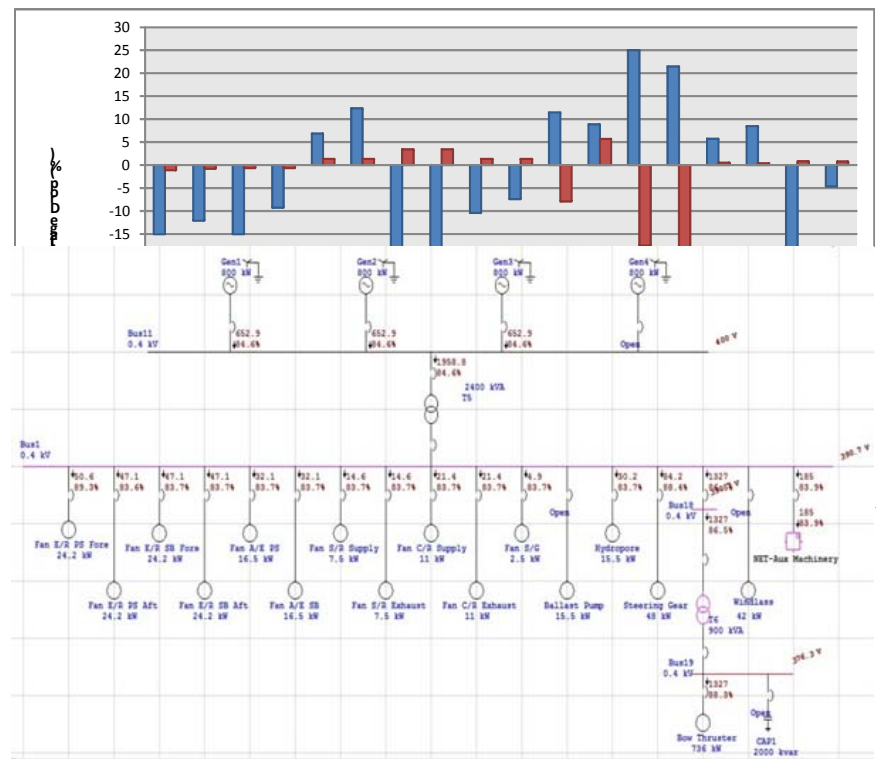

Gambar 6. Kondisi Bow Thruster Sebelum Perbaikan

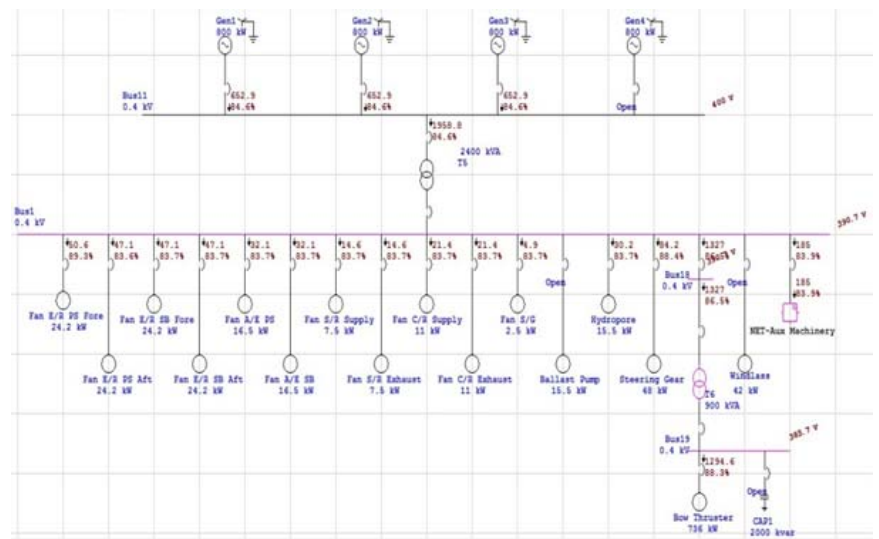

Gambar 7. Kondisi Bow Thruster Setelah Perbaikan

kapal dalam kondisi manuevering beban tertinggi ada pada bow thruster, steering gear dan fresh water cooling pump dengan masing - masing daya $736 \mathrm{~kW}, 48 \mathrm{~kW}$ dan $48 \mathrm{~kW}$. Pada gambar 6 dan tabel 5 kondisi sailing ditunjukkan hasil perhitungan lebih banyak memiliki nilai tegangan jatuh kurang dari standar IEC 5\% [7] dibandingkan dengan hasil simulasi, dikarenakan berbagai faktor eksternal yang mempengaruhi kondisi lapangan. Kondisi maneuvering di kapal penumpang merupakan kondisi dengan beban terbesar saat beroperasi yaitu bow thruster, dimana kondisi ini kapal penumpang memerlukan tambahan generator agar dapat menggunakan bow thruster. Perbandingan hasil perolehan prosentase tegangan jatuh ini bertujuan untuk mengetahui apakah nilai tegangan jatuh kondisi manuevering kapal penumpang yang dihitung secara manual dan dengan menggunakan simulasi software mengalami perbedaan yang signifikan. Pada Gambar 5 dan Tabel 5 kondisi manuevering ditunjukkan hasil perhitungan lebih banyak memiliki nilai

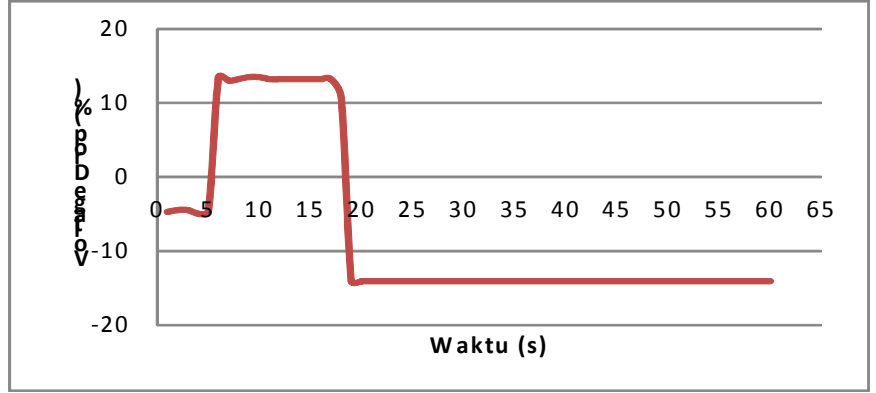

Gambar 9. Grafik Kondisi Bow Thruster Setelah Penambahan Kapasitor

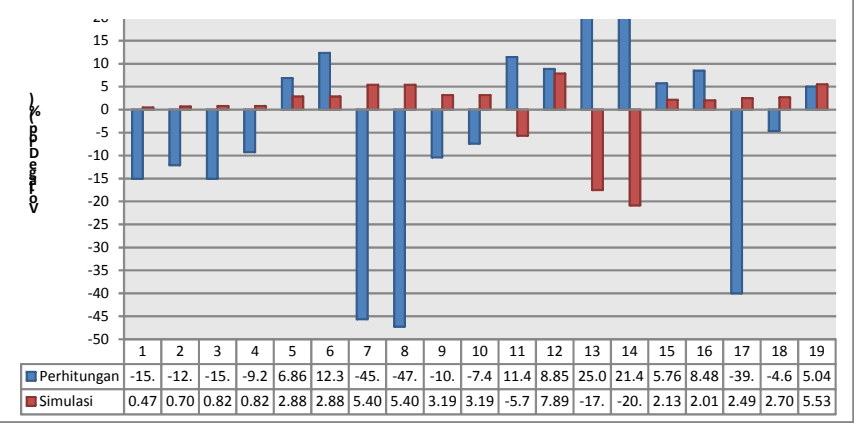

Gambar 5. Grafik Perbandingan Perhitungan dan Simulasi (manuevering)

tegangan jatuh kurang dari standar IEC 5\% [7] dibandingkan dengan hasil simulasi, dikarenakan berbagai faktor eksternal yang mempengaruhi kondisi lapangan sedangkan pada hasil simulasi dipengaruhi oleh faktor kurangnya input data sesuai seperti kondisi di kapal, sehingga membuat hasil simulasi software kurang maksimal dan tidak mendekati nilai perhitungan.

\section{E. Perbaikan Tegangan Jatuh dengan Metode Simulasi}

Hasil analisa tegangan jatuh yang telah dilakukan, didapatkan tegangan jatuh terbesar pada pada kondisi kapal maneuvering dengan beban motor listrik bow thruster. Hasil perbaikan tegangan jatuh melalui hasil simulasi load flow analysis ditunjukkan pada Gambar 7 dan sebelum melakukan perbaikan ditunjukkan pada Gambar 6. Perbaikan tegangan jatuh melalui simulasi load flow analysis pada kondisi maneuvering pada beban terbesar Bow Thruster dengan cara merubah nilai tap transformator 2 dengan daya $900 \mathrm{kVA}$, nilai tap transformator dinaikkan $2,5 \%$ dari nilai tegangan transformator pada sisi sekunder yaitu 400V. Pada awalya ketika belum merubah tap transformator beban Bow Thruster memiliki tegangan terima sebesar $376,3 \mathrm{~V}$ yang membuat bus dari Beban Bow Thruster berwarna merah yang berarti kondisi tersebut tidak aman, sedangkan setelah tap transformator dinaikkan 2,5\% beban Bow Thruster memiliki tegangan terima sebesar $385,7 \mathrm{~V}$ yang membuat bus dari beban Bow Thruster berwarna ungu yang artinya kondisi tersebut aman dan masih bisa ditoleransi oleh standar IEC. [7]

Perbaikan tegangan jatuh juga dilakukan melalui simulasi motor acceleration analysis yang hasilnya ditunjukkan pada Gambar 9 dan hasil sebelum perbaikan ditunjukkan pada Gambar 8.

Perbaikan tegangan jatuh melalui simulasi motor acceleration analysis pada kondisi maneuvering pada beban 
terbesar Bow Thruster dengan cara memberikan beban tambahan yang bersifat kapasitif (kapasitor) dengan nilai tertentu agar dapat mengurangi arus dan memberikan tambahan nilai kepada tengangan serta kapasitor juga dapat meningkatkan nilai faktor daya. Pada Gambar 10 tegangan jatuh hanya terjadi selama 13 detik, kondisi tersebut telah memenuhi standar IEC [7] dan rekomendasi dari IEEE [8] bahwa tegangan jatuh tidak boleh lebih dari 60 detik saat awal operasional motor listrik. [9] Tegangan jatuh terjadi pada detik ke 6 - 18. Kondisi tersebut terjadi karena penambahan kapasitor dengan nilai $2000 \mathrm{kVAr}$. Terjadinya tegangan jatuh terbesar pada titik beban Bow Thruster karena lonjakan arus start yang tidak dapat diminimalisir oleh sklar wye-delta, oleh sebab itu diberi tambahan kapasitor untuk menaikkan nilai tegangan dan fakor daya. Dapat diketahui adanya tambahan beban reaktif dengan satuan VAr dapat memperkecil sudut $\varphi$ sehingga memperbesar nilai faktor daya serta tegangan.

\section{KESIMPULAN}

Kondisi sailing didapatkan tegangan jatuh hasil perhitungan terbesar 25,02\% pada beban MDO Booster Pump dan terkecil $5,76 \%$ pada beban CO FW Pump yang keduanya tidak memenuhi standar IEC 5\%. Pada hasil simulasi terbesar $6,43 \%$ pada beban MDO Transfer Pump yang tidak memenuhi standar IEC 5\% dan terkecil $0,39 \%$ pada beban CO SW Pump. Kondisi loading unloading didapatkan tegangan jatuh hasil perhitungan sebesar 25,02\% pada beban MDO Booster Pump dan terkecil 5,76\% pada beban CO FW Pump yang keduanya tidak memenuhi standar IEC 5\%. Pada hasil simulasi terbesar 5,68\% pada beban MDO Transfer Pump yang tidak memenuhi standar IEC 5\% dan terkecil $1,58 \%$ pada beban CO SW Pump. Kondisi anchoring didapatkan tegangan jatuh hasil perhitungan terbesar $25,02 \%$ pada beban MDO Booster Pump dan terkecil 5,76\% pada beban CO FW Pump yang keduanya tidak memenuhi standar IEC 5\%. Pada hasil simulasi terbesar 5,68\% pada beban MDO Transfer Pump yang tidak memenuhi standar IEC 5\% dan terkecil $0,39 \%$ pada beban CO SW Pump. Kondisi manuevering didapatkan tegangan jatuh hasil perhitungan terbesar $25,02 \%$

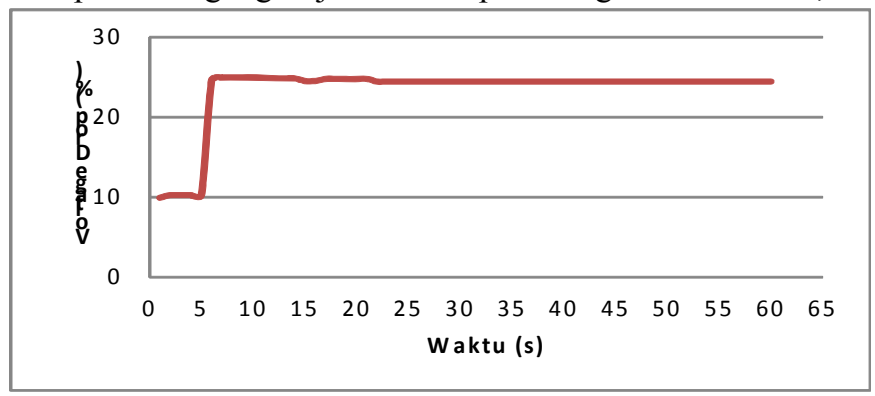

Gambar 8. Grafik Kondisi Bow Thruster Sebelum Penambahan Kapasitor

pada beban MDO Booster Pump dan terkecil 5,04\% pada beban Bow Thruster yang keduanya tidak memenuhi standar IEC 5\%. Pada hasil simulasi terbesar 7,89\% pada beban MDO Transfer Pump yang tidak memenuhi standar IEC 5\% dan terkecil 0,47\% pada beban Fan Engine Room (PS Fore).
Perbaikan tegangan jatuh dilakukan dengan menaikkan tap transformator sebesar 2,5\% dari tegangan sekunder transformator sebesar 400V. Perbaikan pada saat starting Bow Thruster, dengan memberikan kapasitor pada bus penyulang beban Bow Thruster sebersar $2000 \mathrm{kVAr}$, hasilnya tegangan jatuh hanya terjadi 13 detik dan telah memenuhi rekomendasi IEEE. Hasil perhitungan tegangan jatuh di kapal penumpang lebih besar dibandingkan dengan hasil simulasi sehingga menghasilkan nilai error tinggi, disebabkan oleh beberapa faktor antara lain ketidak seimbangan beban listrik, panjang penghantar dari generator ke setiap beban, umur peralatan, kondisi penghantar listrik, sambungan kawat pada titik cabang, kurangnya sistem eksitasi pada generator dan faktor arus starting pada setiap beban motor induksi. Dampak tegangan jatuh menyebabkan kerusakan pada peralatan listrik, mengurangi umur peralatan dan berkurangnya efisiensi peralatan.

\section{DAFTAR PUSTAKA}

[1] Asy'ari, Hasyim. 2011. "Perbaikan Tegangan Jatuh dan Rekonfigurasi Beban Pada Panel Utama Prambanan". Universitas Muhammadiyah, Surakarta.

[2] Kapahi, Rohit. 2013. "Load Flow Analysis of 132 kV Substantion Using ETAP Software". International Journal of Scientific and Engineering Research, IEEE.

[3] Dharamjit \& Tanti, D.K. 2012. "Load Flow Analysis on IEEE 30 bus System". International Journal of Scientific and Research Publications, India, IEEE.

[4] Patil, Piyush S. \& Porate K.B. 2009. "Starting Analysis of Induction Motor. A Computer Simulation by ETAP Power Station". Second International Conference Emerging Trends in Engineering and Technology, IEEE.

[5] Tanjung, Abrar. 2010. “Analisis Penentuan Kapasitor Optimum Untuk Memperbaiki Jatuh Tegangan dan Meminimalkan Rugi - Rugi Daya Pada Sistem Distribusi Menggunakan Program Electric Transient Analysis Program". Universitas Lancang Kuning.

[6] Brice, Charles W. "Voltage-Drop Calculations and Power-Flow Studies for Rural Electric Distribution Lines". University of South Carolina, Columbia, USA.

[7] IEC 60364-8-1, Annex A. "Maximum Voltage Drop Allowed in The Electrical Installations"

[8] IEEE std. 1159-1995. "IEEE Standard Voltage Dip". IEEE, New York

[9] Wahyudy, Firman Rahmat. Sarwito, Sardono. Kurniawan, Adi 2016. "Analisis Arus Starting Transformator Pada Pengoperasian Container Crane di Pelabuhan". Fakultas Teknologi Kelautan, Institut Teknologi Sepuluh Nopember. 